\title{
Der $f$ activates phospholipase $D$ in human T lymphocytes from Dermatophagoides farinae specific allergic individuals: Involvement of protein kinase $C-\alpha$
}

\author{
Jae-Won $\mathrm{Oh}^{1, *}$, Eun-Young Kim ${ }^{2, *}$, \\ Bon-Suk Koo', Ha Baik Lee ${ }^{1}$, Ki Sung Lee ${ }^{3}$, \\ Yong-Seok $\mathrm{Kim}^{2}$ and Joong-SoO $\mathrm{Han}^{2,3,4}$ \\ ${ }^{1}$ Department of Pediatrics \\ ${ }^{2}$ Institute of Biomedical Science \\ Department of Biochemistry \\ College of Medicine, Hanyang University \\ Seoul 133-791, Korea \\ ${ }^{3}$ The Research Center for Bio-Medicinal Resources \\ PaiChai University \\ Daejon 302-735, Korea \\ ${ }^{4}$ Corresponding author: Tel, 82-2-2290-0623; \\ Fax, 82-2-2294-6270; E-mail, jshan@hanyang.ac.kr \\ *The first two authors contributed equally to this work.
}

Accepted 20 September 2004

Abbreviations: HDM, house-dust-mite; IP3, inositol 1,4,5-triphosphate; PA, phosphatidic acid; PBt, phosphatidy butanol; PC, phosphatidylcholine; $\mathrm{PIP}_{2}$, phosphatidylinositol 4,5-bisphosphate; PKC $\alpha$, protein kinase C- $\alpha$; PLC, phospholipase C; PLD, phospholipase $\mathrm{D}$; PMA, phorbol myristate acetate

\section{Abstract}

The major house-dust mite allergen, Der $f 2$, stimulates the phospholipase $D(P L D)$ in T lymphocytes from Dermatophagoides farinae specific allergic individuals. PLD activity increased more than two-fold in $T$ cells from allergic patients compared with those cells from normal controls with maximal responses within $30 \mathrm{~min}$ after exposure of Der $f$ 2. A well-known PLD activator PKC- $\alpha$ was found to be translocated to membrane from cytosol in Der $f$ 2-treated $T$ cells from Dermatophagoides farinae specific allergic individuals. Down-regulation of PKC- $\alpha$ with phorbol myristate acetate pretreatment for $24 \mathrm{~h}$ abolished Der $f$ 2-induced PLD activation. Ro 320432, PKC inhibitor also reduced the effects of Der $f$ 2-induced PLD activation suggesting that PKC $-\alpha$ acts as upstream activator of PLD in Der $f$ 2-treated $T$ cells. Taken together, the present data suggest that Der $f 2$ can stimulate
PLD activity through the PKC- $\alpha$ activation in $T$ cells from Dermatophagoides farinae allergic individuals

Keywords: PKC- $\alpha$, allergy; Der f2; phospholipase D; $\mathrm{T}$ lymphocytes

\section{Introduction}

The study of signal transduction is currently so broad that the only meaningful approach to describe its details is to focus on a specific example and where possible, note how the specifics can be generalized. The hallmark of an allergic reaction also is the secretion of mediators into the tissue or blood, where they act on a variety of organs to produce the hypersensitivity response. In the context of allergic diseases, $T$ lymphocytes play a role in allergic inflammatory reaction. Signal transduction through $T$ lymphocyte antigen receptor is believed to result in the activation of key signal transducing systems such as the phosphatidylinositol 4,5-bisphosphate $\left(\mathrm{PIP}_{2}\right)$-specific phospholipase $\mathrm{C}-\gamma(\mathrm{PLC}-\gamma)$. Phospholipase $\mathrm{C}$ (PLC) generates the second messengers inositol 1,4,5-triphosphate $\left(\mathrm{IP}_{3}\right)$ and diacylglycerol (DG) by metabolizing inositol-containing phospholipids such as phophatidylinositol 4,5-biphosphate. $\mathrm{IP}_{3}$ releases calcium from intracellular storage vesicles, thereby increasing cytosolic-free calcium. DG activates PKC, which in turn induces the activation of various transcription factors. Calcium mobilization may also take place through $G$ protein-dependent activation of PLC. However, $T$ lymphocyte activation via the $T$ cell receptor (TCR) has been shown to occur in the absence of activation of PLC (O'Rourke and Mescher, 1988) and it is demonstrated that PLC-mediated hydrolysis of $\mathrm{PIP}_{2}$ is not sufficient to stimulate $\mathrm{T}$ cell proliferation (Exton, 1994). Therefore, it remains unclear that the mechanism of signal transduction between the ligation of TCR with allergen and secretion of arachidonic acid in allergic inflammatory reaction.

House dust mites (HDMs) are the most important source of indoor aeroallergens (Plattis-Mills TAE and de Weck AL, 1989). Antigens from two common house dust mite species are Dermatophagoides farinae (Der $f$ ) and Dermatophagoides pteronyssinus 
$(\operatorname{Der} p)$. These antigens are group 2 allergens produced by $D$. farinae and $D$. pteronyssinus, respectively, having the amino acid sequence similar to each other (Chua et al., 1990; Yuuki et al., 1991). Der $f$ and $\operatorname{Der} p$ are believed to be the major cause for allergic disease, because group 2 allergen-specific $\lg E$ antibodies are found in sera of allergic patients (Holck et al., 1986; Yasueda et al., 1986, 1989; van der Zee et al., 1988; Heymann et al., 1989; Baldo and Donovan, 1990; Smith et al., 2001; Jeong et al., 2002).

Phospholipase D (PLD) is a widely distributed enzyme that hydrolyzes phosphatidylcholine, a major phospholipids in the cell membrane, to form phosphatidic acid (PA) which acts by itself as a cellular messenger (Exton, 1990, 1999) or can be transformed by PA phosphohydrolase into diacyglycerol (DAG), which is essential for the activation of protein kinase C (PKC) (Nishizuka, 1995). Recently, PLD has been shown to be coupled to TCR in the leukemic $\mathrm{T}$ cell line, Jurkat, resulting in the induction of proliferation of T cells (Reid et al., 1997) and activated by $\operatorname{Der} p 1$ in peripheral blood mononuclear cells from allergic patients (Oh et al., 2000).

In this study, we evaluated whether Der $f 2$ induces PLD activation in T cells isolated from allergic individuals. In addition, we have explored an insight of the mechanism of PLD activation by confirming the involvement of PLD activity in the allergic reaction induced by Der $f 2$ in allergic T-cells.

\section{Materials and Methods}

\section{Subjects}

Six patients who referred with symptoms of allergic diseases had positive skin prick tests to house dust mite (Dermatophagoides farinae) extracts and mean of total serum IgE level was $765.3 \mathrm{IU} / \mathrm{ml}$ and the mean of Der $f$ specific IgE level was $89.7 \mathrm{IU} / \mathrm{ml}$. Der $f$ specific $\lg E$ was measured by using UniCap assay (Upjohn-Pharmacia, Sweden) as shown Table 1. This study was permitted by Ethical Committee of Hanyang University, Guri Hospital. The mean age of the patients was 20.3 years old. Among the healthy people who do not have any clinical and family history of allergy, three healthy volunteers with serum $\lg E$ levels (mean value: $32.8 \mathrm{lU} / \mathrm{ml}$ ) were included.

\section{Skin prick tests and serum IgE levels}

Skin prick tests were performed with allergen extracts of house dust mite (ALK, Copenhagen, Denmark; Greer Lab). Histamine was used as a positive control (10 mg/ml, ALK, Copenhagen, Denmark), and a diluent of an unbuffered saline containing $0.03 \%$ human serum albumin (ALK, Copenhagen, Denmark), was used as a negative control. Reactions to each skin test solution were measured $15 \mathrm{~min}$ after the pricks. The contours of each wheal reaction were outlined with a fine filter tip pen. The contours were then transferred to the record sheet by means of translucent tapes. The size of each wheal was documented as the mean of the longest diameter (a) and the diameter perpendicular to it at its mid-point (b): $(a+b) / 2$. Wheals with more than half of the histamine reaction after substracting the response to the diluent control were considered as expressions of clear-cut positively. Total serum IgE was measured by the paper radioimmunosorbent test (Kabi-Pharmacia, Uppsala, Sweden). The lower detection limit of $\lg E$ was $<1.5 \mathrm{IU} / \mathrm{ml}$.

\section{$\mathrm{CD}^{+} \mathrm{T}$ lymphocytes purification and culture}

Fifty $\mathrm{ml}$ of whole blood was collected from each subject at each setting and total 10 times. Fifty $\mu$ l of Rossette Sep antibody cocktail per $\mathrm{ml}$ of blood was mixed well with blood and then incubated for $20 \mathrm{~min}$

Table 1. The clinical features of allergic individuals.

\begin{tabular}{ccccccc}
\hline Patient & Age $(\mathrm{yr})$ & Sex & Diagnosis & $\begin{array}{c}\text { Serum IgE } \\
(\mathrm{IU} / \mathrm{mL})\end{array}$ & $\begin{array}{c}\text { Der } f \text { specific } \text { IgE } \\
(\mathrm{IU} / \mathrm{mL})\end{array}$ & $\begin{array}{c}\text { Der } f \text { specific } \\
\text { Skin } \mathrm{prick} \text { test }\end{array}$ \\
\hline$A$ & 21 & F & AD, AR, AC & 566 & 85 & +++ \\
$B$ & 18 & F & AS, AR & 1,446 & $>100$ & +++ \\
$C$ & 19 & M & AS & 238 & 95 & +++ \\
$D$ & 21 & F & AS, AD & 328 & 72 & +++ \\
$E$ & 23 & M & AS, AR, AC & 284 & 86 & ++ \\
$F$ & 20 & M & AS, AR & 1,730 & $>100$ & +++
\end{tabular}

$A D$, atopic dermatitis; $A R$, allergic rhinitis; AC, allergic conjunctivitis; AS, asthma; Dp, Dermatophagoides pternyssinus; Df, Dermatophagoides farinae; M, male; F, female; Der f 2 specific lgE was measured by using UniCap assay (Upjohn-Pharmacia, Sweden) 
at room temperature. After incubation, sample was diluted with an equal volume of PBS containing $2 \%$ FBS and mixed thoroughly. This diluted sample was carefully layered on the top of $15 \mathrm{ml}$ of Hypaque Ficoll density medium to isolate autologous $\mathrm{CD} 4^{+} \mathrm{T}$ lymphocytes. The sample was centrifuged for $20 \mathrm{~min}$ at $1,200 \mathrm{~g}$ at room temperature, with the brake off. The enriched cells were removed from the interface between the density medium and plasma and washed with PBS containing $2 \%$ FBS. The isolated cells were washed again with PBS containing $2 \%$ FBS. Onex $10^{6}$ cells of $\mathrm{CD}^{+} \mathrm{T}$ lymphocytes were loaded on each well of 24 well culture plate with $5 \mathrm{mg}$ of $D e r$ $f 2$ recombinant protein and $2 \times 10^{6}$ macrophages as antigen presenting cell (APC) and then incubate for 7 days. After incubating, cultured T lymphocytes were washed with RPMI with $1,000 \mathrm{rpm}$ for $5 \mathrm{~min}$ at $25^{\circ} \mathrm{C}$. Phorbol 12-myristate 13-acetate (PMA, $1.0 \mathrm{ng} / \mathrm{ml}$ ) and $10 \mu \mathrm{g} / \mathrm{ml}$ of PHA-P were added to the each well and recultured for another 3 days. After harvesting the cells, remaining supernatant was kept at $-20^{\circ} \mathrm{C}$ until use.

\section{Generation of monocyte-derived macrophages as antigen presenting cell}

Pheripheral blood mononuclear cells (PBMCs) were isolated from heparinized blood by means of FicollPaque (Biochem, Berlin, Germany) density centrifugation. To enrich $C D 14^{+}$monocytes, $1 \times 10^{6}$ PBMCs per well were incubated for 45 minutes in a 6 -well plate (Costar, Bodenheim, Germany) in modified Dulbecco medium supplemented with $3 \%$ autologous plasma at $37^{\circ} \mathrm{C}$. After washing the nonadherent cells with prewarmed PBS, the remaining monocytes (purity > $90 \%$ ) were incubated in $3 \mathrm{ml}$ of modified Dulbecco medium supplemented with $3 \%$ autologous plasma for 3 days at $37^{\circ} \mathrm{C}$. After washing the nonadherent cells with pre-warmed PBS, the remaining monocytes (purity $>90 \%$ ) were incubated in $3 \mathrm{ml}$ of Dulbecco medium per well supplemented with $1 \%$ heat-inactivated autologous plasma, $1,000 \mathrm{U} / \mathrm{ml} \mathrm{IL-4}$, and $800 \mathrm{U} / \mathrm{ml}$ GM-CSF. Cells were fed with fresh medium every other day. On day 7 , the resulting immature macrophages were pulsed with $10 \mu \mathrm{g} / \mathrm{ml} \operatorname{Der} f 2$ and further

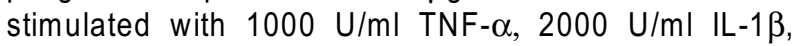
and $1 \mu \mathrm{g} / \mathrm{ml}$ prostaglandin E2 to induce their full maturation. Mature macrophages were harvested 48 $\mathrm{h}$ after stimulation, washed twice, and used for $\mathrm{T}$ lymphocyte culture.

\section{Determination of PLD activity}

PLD activity was determined by the formation of phosphatidylbutanol (PBt) as described elsewhere (Kim et al., 2004). Briefly, T lymphocytes $\left(1 \times 10^{7}\right.$ cells/well) cultured on 6-well plate were metabolically labeled with $2 \mu \mathrm{Ci} / \mathrm{ml}$ of $\left[{ }^{3} \mathrm{H}\right]$ palmitate in serum free medium for $18 \mathrm{~h}$. The cells were then pretreated with $0.3 \%$ 1-butanol for $15 \mathrm{~min}$ before the treatment with $\mathrm{Der}$ $f 2$. In some experiments the cells were treated with phorbol myristate acetate (PMA) $(200 \mathrm{nM})$ for $24 \mathrm{~h}$ to down-regulate PKC before labeling with $\left[{ }^{3} \mathrm{H}\right]$ palmitate. Also, the cells were pre-incubated with Ro 320432 for $30 \mathrm{~min}$, after being labeled with $\left[{ }^{3} \mathrm{H}\right] \mathrm{pal}-$ mitate and serum-starved for $18 \mathrm{~h}$. After treatment of Der $f 2$ for $30 \mathrm{~min}$, the cells were quickly washed with ice-cold PBS and suspended in ice-cold methanol. Lipids were extracted according to the method of Bligh and Dyer (Bligh and Dyer, 1959), and PBt was separated by a thin layer chromatography using a solvent system of ethyl acetate/iso-octane/acetic acid/ water (110:50:20:100, v/v) (Park et al., 1999). The regions corresponding to the authentic $\mathrm{PBt}$ bands were identified with $0.002 \%(\mathrm{w} / \mathrm{v})$ primulin in $80 \%(\mathrm{v} / \mathrm{v})$ acetone, scraped and counted using a liquid scintillation counter.

\section{Immunoblot analysis}

Serum-starved cells on $60 \mathrm{~mm}$ dishes $\left(1 \times 10^{8}\right.$ cells/ dish) were incubated with Der $f 2$ for each indicated times, scraped in PBS and harvested by microcentrifugation. The cells were then resuspended in 200 $\mu$ of lysis buffer $(50 \mathrm{mM} \mathrm{NaCl}, 1 \mathrm{mM} \mathrm{MgCl}, 2 \mathrm{mM}$ EDTA, $1 \mathrm{mM}$ dithiothreitol, $1 \mathrm{mM}$ PMSF, $10 \mathrm{mg} / \mathrm{ml}$ aprotinin, $10 \mathrm{mg} / \mathrm{ml}$ leupeptin, $50 \mathrm{mM}$ Tris- $\mathrm{HCl}, \mathrm{pH}$ 7.4) and disrupted by sonication. The cytosolic fraction was separated from particulate fraction by centrifugation at $100,000 \mathrm{~g}$ for $1 \mathrm{~h}$ using a Beckman TL-100 ultracentrifuge. Proteins from membranes and cytosol were separated by $10 \%$ SDS-PAGE $(10 \mathrm{mg}$ of protein/lane) as described by Laemmli (Laemmli, 1970) and transferred to nitrocellulose membranes using a Bio-Rad semi-dry transfer system. The membranes were blocked for $1 \mathrm{~h}$ with $5 \%$ (w/v) non-fat milk in TTBS (tris-buffered saline containing $0.01 \%$ Tween-20) and then incubated for another $1 \mathrm{~h}$ with diluted specific anti-PKC a or $\beta(1.0 \mu \mathrm{g} / \mathrm{ml})$. Unbound primary antibodies were removed by three washes (10 min each) with TTBS. Detection was performed with the ECL system (Amersham Corp., Buckinghamshire, UK) according to the manufacturer's protocol.

\section{Result and Discussion}

Isolated $\mathrm{T}$ cells from Dermatophagoides farinae specific allergic patients result in an increase of PLD activity determined by a transphosphatidylation reaction with treatment of Der $f 2$. The effects of Der $f 2$ on 
A

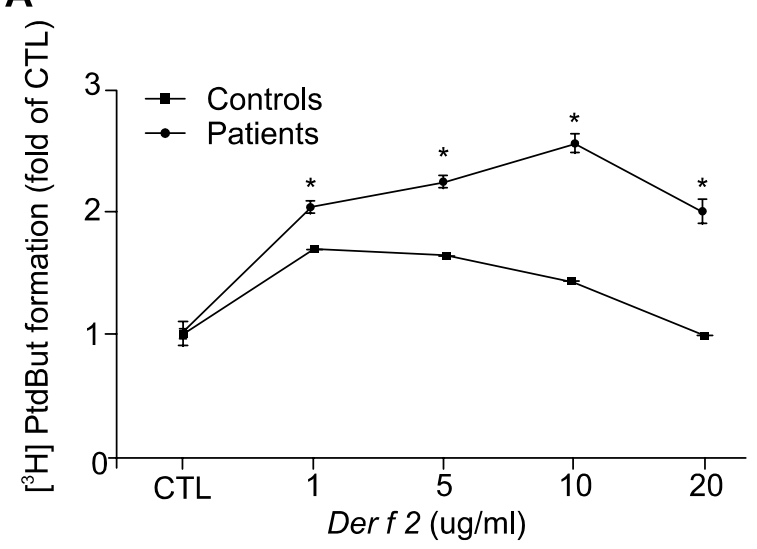

B

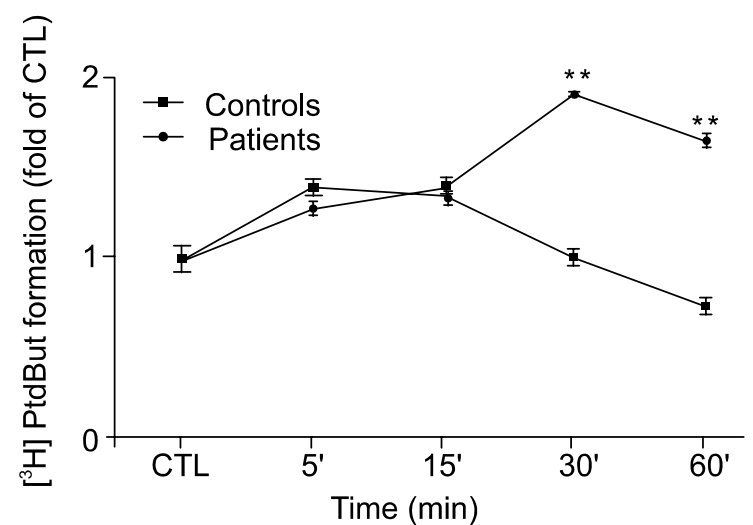

Figure 1. Effects of Der $f 2$ on PLD activity in T lymphocytes from normal (匹) and allergic patients (๑). T lymphocytes were treated with Der $f 2$ on dose-dependent points for 30 min (A) or time-dependent points of $10 \mathrm{mg} / \mathrm{ml}$ concentration (B). T lymphocytes were labeled with [H]palmitate and then treated with Der $f 2$ for the time- or doseindicated. Relative PLD activity was determined by the measurement expressed as a percentage of $\left[{ }^{3} \mathrm{H}\right]$ phospholipids per total labeled lipid. Data shown are means \pm SEM from three separate experiments, each performed in triplicate. Statistical analyses were performed using the student's $t$-test and the asterisk represents significant differences $\left({ }^{*} P<0.05,{ }^{*} P<0.01\right)$ compared with controls.

PLD activity in T lymphocytes from allergic and normal individuals after various doses or times of exposure were shown in Figure 1. A significant effect on PLD activity was seen in T lymphocytes from allergic patients after treatment with $10 \mathrm{mg} / \mathrm{ml}$ of $D e r$ $f 2$ for $30 \mathrm{~min}(P<0.01)$. The PLD activity was increased above the normal values after treatment with Der $f 2$ at each dose point examined, and reached to maximal responses after $10 \mu \mathrm{g} / \mathrm{ml}$ exposure (Figure 1A). At $30 \mathrm{~min}, 10 \mu \mathrm{g} / \mathrm{ml}$ of Der $\mathrm{f} 2$ stimulated PLD activity by 2.0 -fold in allergic patients. (Figure 1B).

To determine whether Der $f$ 2-induced PLD stimulation occurred as a consequence of PKC activation,

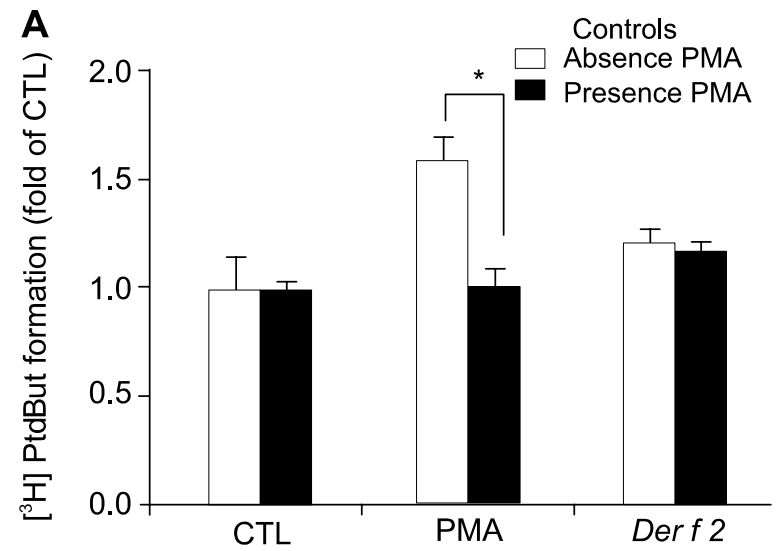

B

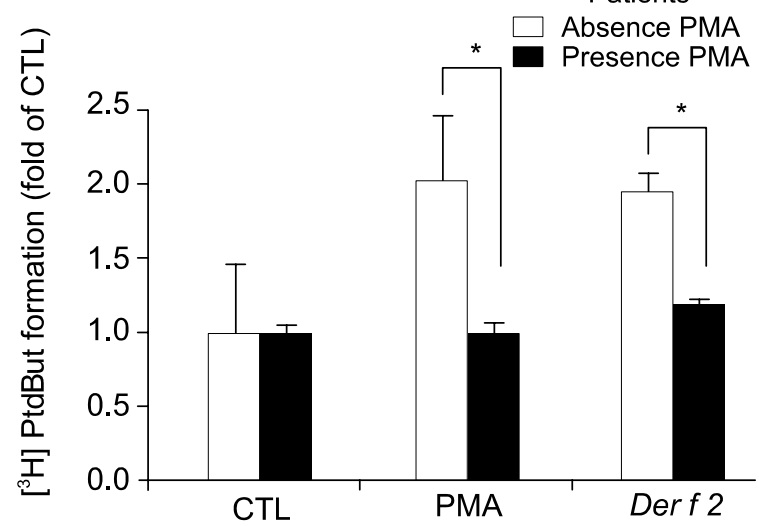

Figure 2. Effect of Der $f 2$ on PLD activation after desensitization of PKC. The cells were incubated with (solid) or without (open) $200 \mathrm{nM}$ PMA for $24 \mathrm{~h}$, at the same time the cells were labeled with $\left.{ }^{3} \mathrm{H}\right]$ palmitate acid and serum-starved. Measurement of PLD activity after the stimulation of $10 \mathrm{mg} / \mathrm{ml} \mathrm{Der} \mathrm{f} 2$ in $T$ lymphocytes was performed using the PLD activity assays as mean \pm SEM from the experiment performed in triplicate. Statistical analyses were performed using the student's $t$-test and the asterisk represents significant differences $(P<0.05)$ compared with $T$ lymphocytes which were not preincubated with $200 \mathrm{nM}$ PMA for $24 \mathrm{~h}$ before stimulation from controls and patients, respectively,

T lymphocytes were exposed to PMA (200 nM) for $24 \mathrm{~h}$ before the treatment for $10 \mathrm{mg} / \mathrm{ml}$ of $\operatorname{Der} f 2$ (Figure 2). As shown in this figure, PKC downregulation by the long-term treatment of PMA had no intrinsic effect on basal PLD activity. PLD activation by $\operatorname{Der} f 2$ in the allergic $T$ lymphocytes was significantly decreased after down-regulation of PKC $(P<$ 0.05 ), suggesting that PKC was involved in PLD activation by Der $f 2$ in the allergic $T$ lymphocytes. To confirm the activation of PKC in Der $f$ 2-treated allergic $T$ lymphocytes, we checked the translocation of PKC from cytosol to membrane. Only translocation of PKC- $\alpha$ to membrane from cytosol was found in 10 $\mathrm{mg} / \mathrm{ml}$ of Der $f 2$ treated allergic $T$ lymphocytes. But 


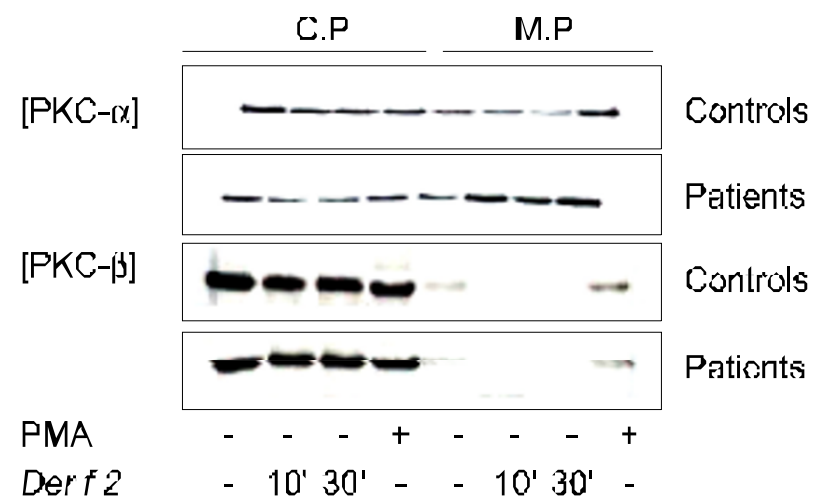

Figure 3. Membrane translocation of PKC in Der $f 2$ treated $T$ lymphocytes. The cells were serum-starved for $24 \mathrm{~h}$ in $60 \mathrm{~mm}$ culture dishes, and stimulated with $10 \mu \mathrm{g} / \mathrm{ml}$ of Der $f 2$ for $10 \mathrm{~min}$ or 30 $\mathrm{min}$. The cells were homogenized and total lysates obtained. $10 \mu \mathrm{g}$ of lysates were analyzed by 10\% SDS-PAGE, and transferred to nitrocellulose membrane. Western blotting using anti-PKC- $\alpha$ and $-\beta$ antibodies, as described in Materials and Methods, was used to identify the proteins. Abbreviations: C.P, cytosol protein; M.P, membrane protein.

the PKC- $\alpha$ translocation was not found in normal T lymphocytes (Figure 3 ). Like PKC- $\beta$, other PKC isozymes such as $\mathrm{PKC}-\varepsilon$, and $-\zeta$, were not responsive to Der $f 2$ in the allergic $T$ lymphocytes (data not shown). This result confirmed that $\operatorname{Der} f$ 2-induced activation of PLD was mediated by PKC- $\alpha$ translocation in the allergic $T$ lymphocytes. To further confirm the role of PKC in PLD, we tried to inhibit PKC with a specific PKC inhibitor. As shown in Figure 4, increased PLD activity seen in the $T$ lymphocytes from allergic individuals induced by Der $f 2$ was not observed in the cells pretreated with the PKC inhibitor, Ro320432 $(P<0.05)$. The observation in cells undergoing inflammation is of particular interest since PLD activity is generally known to be involved in immune responses via production of phosphatidic acid, which lead to generation of DG and elevation of intracellular $\mathrm{Ca}^{2+}$ level, and consequently sphingosine kinase and protein kinase $C$ activation, degranulation, and arachidonic acid release (Knauss et al., 1990; Gemez-Munoz et al., 1994; Liscovitch and Chalifa, 1994; Alirio JM and Janet MA, 2002). Berridge and Irvine (1984) reported that phospholipase $C$ (PLC) had an important role in the early events of $T$ cell activation. PLC is one of the phospholipases in cell, which catalyzes the hydrolysis of $\mathrm{PIP}_{2}$ into the second messenger, inositol 1,4,5-triphosphate $\left(\mathrm{IP}_{3}\right)$ and DAG. Moreover, several studies have emphasized the role of tyrosine phosphorylation in $\mathrm{T}$ cell activation. But some reports have cast doubt on the necessity of phosphoinositide hydrolysis in $\mathrm{T}$ cell activation (June et al., 1990; Mustelin et al., 1990). The activation of PLD resulting in PA production can generate the various intracellular signaling pathway.

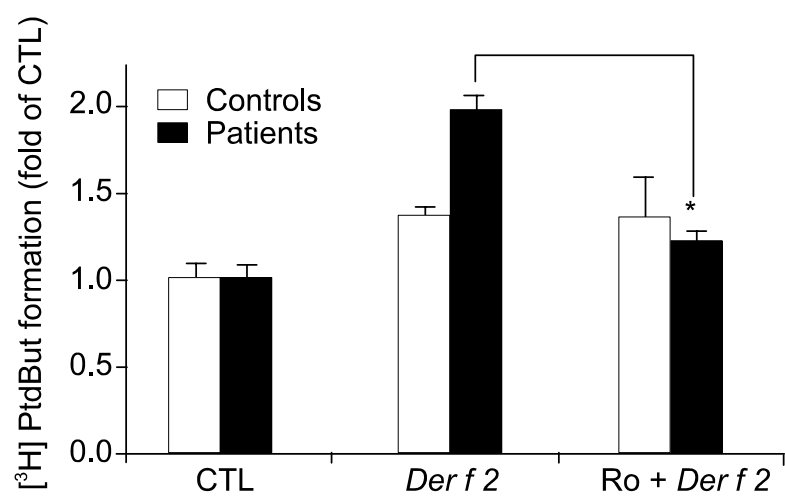

Figure 4. Effects of PKC inhibitor on Der $f 2$ mediated PLD activity. The cells were pre-incubated with Ro 320432 for $30 \mathrm{~min}$, after being labeled with $\left[{ }^{3} \mathrm{H}\right]$ palmitate and serum-starved for $18 \mathrm{~h}$. Measurement of PLD activity after stimulation of Der $f 2$ in $T$ lymphocytes was performed using the PLD activity assays as described in Materials and Methods. Data shown are means \pm SEM from three separate experiments, each performed in triplicate. Statistical analyses were performed using the student's $t$-test and the asterisk represents significant differences $(P<0.05)$ compared with untreated T lymphocytes with PKC inhibitor, Ro 320432.

PA as a product of PLD, has mitogenic properties for various cell types (Exton, 1999). Recently, it is found that PLD has very important role in immune cells signaling via chemokines and chemotactic peptides (Alirio and Janet, 2002). The antigen receptors on mature and immature $T$ cells are also coupled to PLD activation and that this activation is dependent upon PKC (Reid et al., 1997). Previously, we have reported that $\operatorname{Der} p$ 1-induced PLD activation was probably involved in T cell activation of PBMC cells and Der $p 1$-induced PLD activation partially occurred as a consequence of PKC activation (Oh et al., 2000). There are many evidences that $P K C$ is a major mediator to activate PLD in response to various agonists. It has been known that treatment of many cell types, with agonists that induce PIP2 hydrolysis or with phorbol esters, stimulates PLD activity, implying that PLD activity can be regulated by PKC (Kiss, 1996). The expression of mRNA for PKC- $\alpha,-\beta$, $-\varepsilon$, and $\zeta$, but not $-\gamma$ or $-\delta$ isozymes, has been detected in T cells (Freire-Moar et al., 1991; Harris et al., 1995; Wang XD et al., 1995). In the present experiment, Der $f$ 2-induced PLD activation was significantly abrogated by prior long-term exposure to PMA, which has been demonstrated to lead to PKC down-regulation in various cell types (Kraft et al., 1982) and Der $f$ 2-induced PKC $\alpha$ translocation was found in severe allergic patient $T$ cells, suggesting that PLD was activated by PKC $\alpha$ when stimulated allergic $T$ cell with Der $f 2$. (Figure 2 and 3 ).

In this study, when the PKC was down-regulated, Der $f$ 2-induced PLD activation of control T cells was 
weaker than that of allergic $\mathrm{T}$ cells. Moreover, Der $f$ 2-induced PLD activation of control T cells was not inhibited by long-term treatment of PMA to desensitize PKC (Figure 2), indicating that another activator, not PKC, might be needed for Der $f$ 2-induced PLD activation in control $T$ cells. PLD activity can be regulated by multiple types of signals (Liscovitch and Chalifa, 1994). Both heterotrimeric and low molecular weight $G$ proteins have been implicated in PLD activation. Many investigators suggested that small molecular weight $G$ proteins such as ADP-ribosylation factor (ARF) and RhoA are involved in agonistinduced PLD activation in several cell types (GomezCambronero and Keire, 1998). In case of T cells, a recent report demonstrated that PLD activation was also activated by small molecular weight $G$ proteins, ARF and RhoA (Bacon et al., 1998). However, it is not yet clear whether these small molecular weight $G$ proteins may be the regulator for $\operatorname{Der} f$ 2-induced PLD activation. In this study, PKC- $\alpha$ translocation in allergic $T$ cells was occurred from cytosol to membrane by treatment of Der $f 2$. Inhibition of PKC- $\alpha$ with Ro320432 inhibited PLD activation induced by Der $f 2$ treatment to allergic $\mathrm{T}$ cells (Figure 3 and 4). Taken together, we can suggest that PKC- $\alpha$ play an important role in Der $f$ 2-induced PLD activation.

In conclusion, the present results demonstrated that Der $f 2$ induced activation of PLD in T cells from Dermatophagoides farinae specific allergic individuals and PKC- $\alpha$ played major role in Der $f$ 2-induced PLD stimulation. In this study, we could not investigate possible involvements of the other PLD activators such as small molecular $G$ proteins and certain tyrosine kinases in Der $f$ 2-induced PLD activation pathways because of difficulty to prepare $T$ cells from allergic patients. Further investigation will be required to fill in the missing links, and to demonstrate the relevance of $\operatorname{Der} f 2$-induced PLD activation pathway in clinical setting.

\section{Acknowledgement}

This study was supported financially by the KOSEF and MOST through the Research Center for BioMedicinal Resources (Bio-Med RRC), PaiChai University and partly by a research fund of Hanyang University (HY-2001), Korea.

\section{References}

Alirio JM, Janet MA. Phospholipase D and immune receptor signaling. Immunology 2002;14:49-55

Bacon KB, Schall TJ, Dairghi DJ. RANTES activation of phospholipase $D$ in Jurkat T cells: requirement of GTPbinding proteins ARF and Rho. J Immunol 1998;160:1894-
900

Baldo BA, Donovan GR. House dust mite (Dermatophagoides spp.) allergens: research directions and priorities in the 1990s. In Molecular Approaches to the Study of Allergens (Baldo BA, eds), 1990;138-48, Karger Basel

Berridge MJ, Irvine RF. Inositol trisphosphate, a novel second messenger in cellular signal transduction. Nature 1984; $312: 315-21$

Bligh KM, Dyer WJ. A rapid method of total lipid extraction and purification. Can J Biochem Physiol 1959;37:911-17

Chapman MD, Platts-Mills TAE. Purification and characterization of the major allergen from Dermatophagoides pteronyssinus antigen P1. J Immunol 1980;125:587-92

Chapman MD, Smith AM, Vailes LD, Arruda LK. Recombinant mite allergens. New technologies for the management of patients with asthma. Allergy 1997;52:374-79

Chua KY, Doyle CR, Simpson RJ, Turner KJ, Stewart GA, Thomas WR. Isolation of CDNA coding for the major mite allergen Der $p 2$ by $\operatorname{lgE}$ plaque immunoassay. Int Arch Allergy Appl Immunol 1990;91:118-23

de Blay F, Heymann PW, Chapman MD, Platts-Mills TA. Airborne dust mite allergens: comparison of group II allergens with group I mite allergen and cat-allergen $\mathrm{Fel} d \mathrm{l}$. J Allergy Clin Immunol 1991;88:919-26

Exton JH. Signaling through phosphatidylcholine breakdown. J Biol Chem 1990;265:1-4

Exton JH. Phosphatidylcholine breakdown and signal transduction. Biochem Biophys Acta 1994;1212:26-34

Exton JH. Phospholipase D; enzymology, mechanism of regulation, and function. Physio Rev 1997;77:303-20

Exton JH. Regulation of phospholipase D. Biochim Biophys Acta 1999;1439:121-33

Freire-Moar J, Cherwinski H, Hwang F, Ransom J, Webb $D$. Expression of protein kinase $C$ isozymes in thymocyte subpopulations and their differential regulation. J Immunol $1991 ; 147: 2405-9$

Gomez-Cambronero J, Keire P. Phospholipase D: A novel major player in signal transduction. Cell Signal 1998;10: 387-97

Gomez-Munoz A, Martin A, Obrien L, Brindley DN. Cellpermeable ceramides inhibit the stimulation of DNA synthesis and phospholipase $\mathrm{D}$ activity by phosphatidate and lysophosphatidate in rat fibroblasts. J Biol Chem 1994;269;2937-43

Harris W, Gollapudi S, Gupta S. Anti-CD3-induced changes in protein kinase $C$ isozymes expression in human $\mathrm{CD} 4+$ and CD8+ T lymphocytes. J Clin Immunol 1995;15: 232-43

Heymann PW, Chapman MD, Aalberse RC, Fox JW, Platts-Mills TAE. Antigenic and structural analysis of group 2 allergens (Der $f 2$ and $\operatorname{Der} p 2$ ) from house dust mite (Dermatophagoides spp.) J Allergy Clin Immunol 1989;83: 1055-67

Holck A, Dale S, Sletten K. Purification and characterization of a major allergen from the house dust mite Dermatophagoides farinae. Allergy 1986;41:408-17 
Howe LR, Weiss A. Multiple kinases mediate T cell receptor signaling. Trends Biochem Sci 1995;20:59-67

Jeong KY, Jin HS, Oh SH, Hong CS, Lee IY, Ree HI, Yong TS. Monoclonal antibodies to recombinant Der $f 2$ and development of a two-site ELISA sensitive to major Der $f$ 2 isoallergen in Korea. Allergy 2002;57:29-34

June $\mathrm{CH}$, Fletcher MF, Ledbetter JA, Samelson LE. Increases in tyrosine phosphorylation are detectable before phospholipase $\mathrm{C}$ activation after $\mathrm{T}$ cell receptor stimulation. J Immunol 1990;144:1591-9

Kim J, Min G, Bae YS, Min DS. Phospholipase D is involved in oxidative stress-induced migration of vascular smooth muscle cells via tyrosine phosphorylation and protein kinase. Exp Mol Med 2004;36:103-9

Kiss Z. Direct proof that phorbol ester accelerates the use of choline phosphate for phosphatidylcholine synthesis in intact cells. Arch Biochem Biophys 1996;335:191-6

Knauss TC, Jaffer FE, Abboud HE. Phosphatidic acid modulates DNA synthesis, phospholipase $C$, and platelet-derived growth factor mRNAs in cultured mesangial cells. Role of protein kinase C. J Biol Chem 1990;265:14457-63

Kraft AS, Anderson WB, Cooper HL, Sando JJ. Decrease in cytosolic calcium/phospholipids-dependent protein kinase activity following phorbol ester treatment of EL4 thymoma cells. J Biol Chem 1982;257:13193-96

Liscovitch M, Chalifa V. Signal-activated phospholipase D. In signal-activated phospholipases (Liscovitch M, eds), 1994; 31-63, Landes, Austin

Looney RJ, Pudiak D, Rosenfeld SI. Cytokine production by mite-specific T-cells from donors with mild aptopic disease. J Allergy Clin Immunol 1994;93:476-83

Miyamoto T, Oshima S, Ishizaki T, Sato SH. Allergenic identity between the common floor mite (Dermatophagoides farinae. Hughes, 1961) and house dust as a causative antigen in bronchial asthma. J Allergy 1968;42:14-28

Mustelin T, Coggeshall KM, Isakov N, Altman A. T cell antigen receptor-mediated activation of phospholipase $\mathrm{C}$ require tyrosine phosphorylation. Science 1990;247:1584-7

Nishizuka $Y$. Protein kinase $C$ and lipid signaling for sustained cellular response. FASEB J 1995;9:484-96

O'Brien RM, Thomas WR, Wooton AM. T-cell responses to the purified major allergens from the house dust mite Dematophagoides pteronyssinus. J Allergy Clin Immunol 1992; 89:1021-31

Oh JW, Kim JH, Lee KS, Han JS. Major house dust mite allergen, Der $p 1$, activates phospholipase $D$ in human peripheral blood mononuclear cells from allergic patients: Involvement of protein kinase C. Exp Mol Med 2000;32: 67-71
ORourke AM, Mescher MF. T cell receptor-mediated signaling occurs in the absence of inositol phosphate production. J Biol Chem 1998;263:18594-600

Park BJ, Kim JH, Han JS, Jung PM. Effect of ceramide on apoptosis and phospholipase D activity in FRTL-5 thyroid cells. Exp Mol Med 1999;31:142-50

Platts-Mills TAE, De Weck AL. Dust mite allergens and asthma - A world wide problem. J Allergy Clin Immunol 1989;83:416-27

Rawle FC, Mitchell EB, Platts-Mills TAE. T-cell responses to the major allergen from the house dust mite Dermatophagoides pteronyssinus, antigen $\mathrm{P} 1$ : comparision of patients with asthma, atopic dermatitis, and perennial rhinitis. J Immunol 1984;133:195-201

Reid PA, Gardner SD, Williams DM, Harnett MM. The antigen receptors on mature and immature $T$ lymphocytes are coupled to phosphatidylcholine-specific phospholipase $D$ activation. Immunology 1997;90:250-6

Satoshi Miike MD, Hirohitokita MD. Human eosinophils are activated by cysteine proteases and release inflammatory mediators. J Allergy Clin Immunol 2003;111:704-13

Smith AM, Benjamin DC, Hozic N, Derewenda U, Smith WA, Thomas WR, Gafvelin G, van Hage-Hamsten M, Chapman $M D$. The molecular basis of antigenic cross-reactivity between the group 2 mite allergens. J Allergy Clin Immunol $2001 ; 107: 977-84$

Thomas WR, Smith W. An update on allergens: Housedust-mite allergens. Allergy 1998;53:821-32

van der Zee JS, Van Sweieten P, Jansen HM, Aalberse RC. Skin tests and histamine release with $\mathrm{P} 1$-depleted Dermatophagoides pteronyssinus body extracts and purified P1. J Allergy Clin Immunol 1998;81:884-96

Voorhorst R, Spieksma FT. Correspondence: of mites and men. J Allergy 1967;40:357-58

Wang XD, Kiang JG, Smallridge RC. Identification of multiple protein kinase $C$ isoforms in FRTL-5 thyroid cells. Thyroid 1995;5:137-40

Yasueda H, Mita H, Yui $Y$, Shida T. Isolation and characterization of two allergens from Dermatophagoides farinae. Int Archs Allergy Appl Immunol 1986;81:214-23

Yasueda $H$, Mita H, Yui $Y$, Shida T. Comparative analysis of physicochemical and immunochemical properties of the two major allergens from Dermatophagoides pteronyssinus and the corresponding allergens from Dermatophagoides farinae. Int Archs Allergy Appl Immunol 1989;88:402-7

Yuuki T, Okumura Y, Ando T, Yamakawa H, Suko M, Haida $\mathrm{M}$, Okudaira $\mathrm{H}$. Cloning and expression of CDNA coding for the major house dust mite allergen Der $f 2$ in Escherichia coli. Agric Boil Chem 1991;55:1233-38 